\title{
Maternal Food Restriction During Lactation Reduces Mandible Growth of the Female Offspring in Adulthood: Experimental and Morphometric Analysis
}

\author{
Restricción Alimentaria Materna Durante la Lactancia Reduce el Crecimiento de la Mandíbula \\ de las Crías Hembras en la Edad Adulta: Análisis Experimental y Morfométrico
}

"Hugo V. M. Degani Junior; "Viviane A. Nunes; "Ewerton C. Bezerra; "* Cristiane F. Ramos; "Mauro R. Rodrigues; **** Marcelo Abidu-Figueiredo; "Gilberto P. Cardoso \& "Marcio A. Babinski

DEGANI JUNIOR, H. V. M.; NUNES, V. A.; BEZERRA, E. C.; RAMOS, C. F.; RODRIGUES, M. R.; ABIDU-FIGUEREIDO, M.; CARDOZO, G. P. \& BABINSKI, M. A. Maternal food restriction during lactation reduces mandible growth of the female offspring in adulthood: Experimental and morphometric analysis. Int. J. Morphol., 29(2):598-603, 2011.

SUMMARY: The aim of this study was to evaluate the effects of maternal protein and energy restriction during lactation on mandible dimensions of pups (female) at aging. At parturition, Wistar rat dams were randomly assigned to the following groups: 1) control group (C) - free access to a standard laboratory diet containing $23 \%$ protein, 2) protein-energy restricted group (PER) - free access to an isoenergetic, protein-restricted diet containing 8\% protein, and 3) energy-restricted group (ER) - fed with restricted amounts of a standard laboratory diet. At weaning (d21), all pups were separated of dams and received free access to a standard laboratory diet containing 23\% protein until 90 days (d90), when the rats were anesthetized and sacrificed. The dimensions of excised pup mandible were measured directly using pre-established 3 anatomical points. Morphometric analysis showed that most of the measurements in the ER and PER groups were significantly lower than in the control group, with the greatest reductions occurring in the PER group. These results show that protein and energy restriction during lactation have an important influence on pup mandible development and continue through the aging process.

KEYWORDS: Growth and development; Morphometry; Rats; Mandible; Undernutrition.

\section{INTRODUCTION}

Protein malnutrition may occur in any phase of growth, i.e., gestation, suckling, weaning or later periods, and the specific effects associated with each period may or may not be similar and/or reversible (Desai et al., 1980; Miller \& German, 1999; Allipi et al., 2002). In early life there is a serious challenge to which the system should try to adjust to maintain adequate growth and survival rates. Some authors showed that the nutritional status of the mother during gestational and lactation periods is essential to the normal growth and development in humans (Barker, 2000) or in experimental animals (Passos et al., 2000).

The quantity or quality of nutrition at those critical periods may have permanent consequences for later life. One of the mechanisms to adapt to inadequate supply of nutrients is slowing down the rate of cell division in tissues and organs, which may lead to an altered "programming" of the structure and function of the system (Lucas, 1998). In the human being, malnutrition induced in early life is associated with an increased risk to develop type 2 diabetes, hypertension, and cardiovascular disease at long term (Barker).

Undernutrition has a wide variety of effects on the endocrine system (Moura et al., 1996; Cónsole et al., 2001; Teixeira et al., 2002;) that can reduce the body weight (Passos et al., 2000; Teixeira et al., 2002; Santos et al., 2004; Fernandes et al., 2007; Fernandes et al., 2008). Indeed, the use of body weight as a measure of growth has shown that protein malnutrition produces smaller-sized individuals (Pucciarelli, 1981; Cotheran et al., 1985; Cameron \&

\footnotetext{
* Department of Morphology, Biomedical Center, Fluminense Federal University, Brazil.

** Department of Anatomy, Biomedical Center, State University of Rio de Janeiro, Rio de Janeiro, Brazil.

*** Department of Animal Anatomy, Rural of Rio de Janeiro University, Rio de Janeiro, Brazil.
} 
DEGANI JUNIOR, H. V. M.; NUNES, V. A.; BEZERRA, E. C.; RAMOS, C. F.; RODRIGUES, M. R.; ABIDU-FIGUEREIDO, M.; CARDOZO, G. P. \& BABINSKI, M. A. Maternal food restriction during lactation reduces mandible growth of the female offspring in adulthood: Experimental and morphometric analysis. Int. J. Morphol., $29(2): 598-603,2011$.

Eshelman, 1996, Kasper et al., 2005; Fernandes et al., 2007; Fernandes et al., 2008).

Regarding the skeletal system, several experimental models were designed to evaluate macroscopic and microscopic remodeling in rats. It has been shown that food (Kenney et al., 1994; Miller \& Bowman, 1998; Morohashi et al., 2000; Kawahara et al., 2002) and mineral restriction (Rodriguez et al., 1998; Medeiros et al., 2002; Chen et al., 2002) can inhibit growth and promote morphology remodeling. Thus, the goal of the present study was to examine the effect of maternal protein and energy malnutrition during lactation on mandible growth of the female offspring in the adulthood.

\section{MATERIAL AND METHOD}

Animal care. The study design and its experimental protocols were approved by the Animal Care and Use Committee of the State University of Rio de Janeiro, which based its analysis on the Guide for the Care and Use of Laboratory Animals (NRC, 1995; Bayne, 1996). The experiments described here were done in compliance with the general guidelines of the Brazilian College for Animal Experimentation (COBEA).

Animals. Wistar rats obtained from Biomedical Center, State University of Rio de Janeiro were housed at $25 \pm 1^{\circ} \mathrm{C}$ and on a $12 \mathrm{~h}$ light/dark cycle (lights on from 7:00 a.m. to 7:00 p.m.) throughout the experiment (NRC). Three-month-old, six virgin female rats (Quinn, 2005) were housed with one male rat at a proportion of 2:1. After mating, each female was placed in an individual cage with free access to water and food until delivery. Then, the number

Table I. Composition of control and protein-restricted diets. aThe principal protein resources were soybean wheat, steak, fish and amino acids. bStandard diet for rats (Nuvilab-Nuvital Ltd., Curitiba, Paraná, Brazil). cThe protein-restricted diet was prepared in our laboratory by replacing part of the protein content of the control diet with cornstarch. The amount of the latter was calculated to replace the same energy content of the control diet. dVitamin and mineral mixtures were formulated to meet the American Institute of Nutrition AIN-93G recommendation for rodent diets (Reeves et al., 1993).

\begin{tabular}{lcc}
\hline & Controlb & Protein-restricted $^{\mathbf{c}}$ \\
\hline Ingredients $(\mathrm{g} / \mathrm{kg})$ & & \\
Total proteina & 230.0 & 80.0 \\
Corn starch & 676.0 & 826.0 \\
Soybean oil & 50.0 & 50.0 \\
Vitamin mixtured $^{\mathrm{d}}$ & 4.0 & 4.0 \\
Mineral mixture $^{\mathrm{d}}$ & 40.0 & 40.0 \\
Macronutrient composition (\%) & & \\
Protein & 23.0 & 8.0 \\
Carbohydrate & 66.0 & 81.0 \\
Fat & 11.0 & 11.0 \\
Total energy $(\mathrm{kJ} / \mathrm{kg})$ & 17038.7 & 17038.7 \\
\hline
\end{tabular}

of pups born was similar, six per pregnant rat, totaling 12 per group. All pups showed good health condition. Besides, no pups showed any statistical difference in body weight or linear growth.

Experimental procedures and diets. Pregnant Wistar rats were separated at delivery into three groups: 1) control group (C) - with free access to a standard laboratory diet (in grams per 100g) containing 23\% protein, $68 \%$ carbohydrate, 5\% lipid, $4 \%$ salts and $0.4 \%$ vitamins, $17,038.7$ total energy $(\mathrm{kJ} / \mathrm{kg}) ; 2)$ protein-energy-restricted group (PER) - with free access to an isoenergetic, protein-restricted diet containing $8 \%$ protein, and 3 ) energy-restricted group (ER) - fed with a standard laboratory diet in restricted quantities that was calculated based on mean ingestion of the PER group. We have previously shown that the PER group consumed about $60 \%$ of the amount consumed by the control group, despite having free access to food (Passos et al.). Hence, the ER and PER groups ingested essentially the same amount of food.

The protein-restricted diet was prepared in our laboratory (Table I) by using the control diet with replacement of part of its protein content with cornstarch. The amount of the latter was calculated to replace the same energy content of the control diet. Vitamin and mineral mixtures were formulated to equal those found in the control diet and to meet the American Institute of Nutrition AIN-93G recommendation for rodent diets (Reeves et al., 1993). Within $24 \mathrm{~h}$ of birth, male pups were removed so that only six pups (female) were kept per dam, as it has been shown that this procedure maximizes lactation performance (Fishbeck \& Rasmussen, 1987).

Malnutrition started at birth, which was defined as day 0 of lactation (d0), and ended at weaning (d21) (Quinn). To evaluate the nutritional state, body weight of the pups was monitored during the 21 days throughout the experiment. After weaning (d22-d90), female pups of the same treatment group were housed in group of three animals per cage, and given unlimited access to food and water until adulthood (d90) (Quinn), when the animals were anesthetized with a lethal thiopental anesthesia $(0,15 \mathrm{ml} / 100 \mathrm{~g} / \mathrm{body}$ weight) and perfused through the left ventricle with buffered saline followed by formalin solution.

The mandible were excised, dissected and fixed in formalin $4 \%$ in $0.1 \mathrm{M}$ in phosphate buffer $(\mathrm{pH}$ 7.4), and then, assessed using morphometric parameters (Table II). 
DEGANI JUNIOR, H. V. M.; NUNES, V. A.; BEZERRA, E. C.; RAMOS, C. F.; RODRIGUES, M. R.; ABIDU-FIGUEREIDO, M.; CARDOZO, G. P. \& BABINSKI, M. A. Maternal food restriction during lactation reduces mandible growth of the female offspring in adulthood: Experimental and morphometric analysis. Int. J. Morphol., 29(2):598-603, 2011.

Table II. Morphometric parameters ( $\mathrm{mm}$ ) of mandibles in adult female rats (d90).

$\begin{array}{ll}\text { Parameters } & \text { Vestibular margin of the alveolar process (lower central incisor) - Posterior margin of the mandible angle. } \\ \text { M-M' } & \begin{array}{l}\text { Anterosuperior junction of the mandible body with the mandible branch - Posteri or mas seteric tuberosity, } \\ \text { on mandibular inferior margin. }\end{array} \\ \text { M-R } & \begin{array}{l}\text { Anterosuperior junction of the mandible body with the right mandible branch - Anterosuperior junction } \\ \text { of the mandible body with the Left mandible branch. }\end{array}\end{array}$

Statistical analysis. Data was reported as the mean \pm standard deviation (SD). Statistical significance of experimental observations was determined by the one-way analysis of variance, followed by Newman Keuls test to compare the 3 experimental groups. The level of significance was set at $\mathrm{p}<0.05$. All statistical analyses were done using GraphPad Prism 4 statistical software (GraphPad Inc., CA, USA).

\section{RESULTS}

The mandible morphometric measurements are shown in Table III. The values for parameters C-L, M-R in the ER and PER groups were significantly smaller than those of the control group.

\section{DISCUSSION}

The development of the craniofacial skeleton is critically affected by malnutrition, and several studies have examined the effect of nutritional deficiencies on bone growth during gestation (Pucciarelli \& Oyhenart, 1987b), lactation (Pucciarelli \& Oyhenart; Miller \& German; Fernandes et al., 2008), gestation and lactation (Toews \& Lee, 1975), and the postweaning period (Riesenfeld, 1967; Riesenfeld, 1973; Pucciarelli). On the other hand, different forms of retarded craniofacial growth have been reported, depending on the type of malnutrition and/or its intensity, as well as the period in which the stress was applied (Fernandes et al., 2008). Additionally, growth of the craniofacial components in rats may be influenced by sex, breed or strain, and nutritional status (Pucciarelli; Pucciarelli $\&$ Oyhenart). Because there is no consensus regarding the morphometric parameters that should be analyzed.
In previous study (Fernandes et al., 2008), skulls underdevelopment was evident in weaned rats (d21) whose mothers were fed PER or ER diets during lactation and those changes were accompanied by quantitative alterations in the body weight. In present study we observed that abnormalities remain until adulthood (90D (Quinn)), even after reestablishing normal diet (control) for study groups (ER and PER) at weaning period. We observed that abnormalities at the lactation period $(\mathrm{d} 21)$ remained until adulthood. This can be observed at gross results, a delay in mandible growth abnormalities (Table III).

These findings confirm previous observations (Ramos et al., 1997; Passos et al.; Teixeira et al.) that undernutrition (ER and PER groups) leads to a lower weight gain from the first day of lactation onwards. The deficiency in body weight gain seen in malnourished offspring could result from a reduction or absence of growth hormone $(\mathrm{GH})$ because food deprivation reduces the number of $\mathrm{GH}$ secretory cells, as shown by immunostaining of hypothalamic sections for GH-releasing hormone (GHRH) and quantification of the mRNA levels for GHRH and GH (Brogan et al., 1997; Cónsole et al.).

Another hypothesis for the retardation in bone development seen in PER and ER rats may be related to inadequate maturation of the hypothalamic-hypophysealtarget organ (bone) axis in the offspring as a result of maternal malnutrition. In the present case low hormonal stimulation may be insufficient to stimulate normal development of the craniofacial bones, e.g., mandible. The loss of body weight and osseous tissue in the ER and PER groups may be caused by a reduction in the rate of metabolism. Part of this decline results from a reduced energy intake and a consequent decrease in the thermal effect of food, while part is attributable to the reduced size of the mass available for metabolization. However, whether there

Table III. Mandible morphometric measurements.

\begin{tabular}{lccccc}
\hline Parameters & Controls & ER & PER & n & p Value \\
\hline C-L & $23.56 \pm 0.61$ & $21.56 \pm 2.01$ & $21.24 \pm 1.45$ & 6 & $0.04^{*}$ \\
M-M & $12.14 \pm 0.98$ & $11.08 \pm 0.53$ & $10.73 \pm 0.74$ & 6 & $0.37^{*}$ \\
M-R & $6.30 \pm 0.49$ & $5.53 \pm 0.11$ & $5.37 \pm 0.17$ & 6 & $0.002^{*}$ \\
\hline
\end{tabular}

Data presented as the mean percentage \pm SD. *Statistically significant, ANOVA test. 
DEGANI JUNIOR, H. V. M.; NUNES, V. A.; BEZERRA, E. C.; RAMOS, C. F.; RODRIGUES, M. R.; ABIDU-FIGUEREIDO, M.; CARDOZO, G. P. \& BABINSKI, M. A. Maternal food restriction during lactation reduces mandible growth of the female offspring in adulthood: Experimental and morphometric analysis. Int. J. Morphol., 29(2):598-603, 2011.

is also a metabolic adaptation, defined here as a reduction in the metabolic rate that is disproportional to the decreased size of the respiring mass, is a subject of continued debate.

The present results agree with reports showing that undernutrition during lactation delays offspring growth (Engelbregt et al., 2000; Delemarre-van de Wall et al., 2002) and craniofacial development (Pucciarelli \& Oyhenart; Miller \& German; Fernandes et al., 2008). Based on the present findings of an attenuated mandible development in the ER and PER groups, as shown by the measurements (Table III), agree with other studies of, who showed that the viscerocranium is used during suckling and breathing, and that its growth is continuously subject to muscular loading. We believe that in the present study, the nutritional influence was stronger than the biomechanical influence.

Malnutrition may occur in any phase of growth, that is, gestation, suckling, weaning or later periods, and the specific effects associated with each period may or may not be similar and/or reversible (Miller \& German; Alippi et $a l$.). In our study, it was observed that the maternal nutritional state during lactation leads to persistent alterations of the mandible skeleton development. This attenuated growth involved the mandible was probably affected by the maternal nutritional status associated by biomechanical stress on the masticatory function.

In conclusion, morphometric analysis of the mandible demonstrated a significant reduction in the parameters of the two treated groups, specially the PER group, when compared to the controls.

\section{ACKNOWLEDGEMENTS}

This work was supported by grants from the National Council of Scientific and Technological Development (CNPq), Foundation for Research Support of Rio de Janeiro (FAPERJ), Brazil.

DEGANI JUNIOR, H. V. M.; NUNES, V. A.; BEZERRA, E. C.; RAMOS, C. F.; RODRIGUES, M. R.; ABIDU-FIGUEREIDO, M.; CARDOZO, G. P. \& BABINSKI, M. A. Restricción alimentaria materna durante la lactancia reduce el crecimiento de la mandíbula de las crías hembras en la edad adulta: análisis experimental y morfométrico. Int. J. Morphol., 29(2):598-603, 2011.

RESUMEN: El objetivo de este estudio fue evaluar los efectos de la restricción de la proteína materna y de la energía durante la lactancia sobre las dimensiones de la mandíbula de crías (hembras) durante la vida. En el parto, las crías de ratas Wistar fueron agrupadas aleatoriamente en los siguientes grupos: 1) control (C) - con acceso libre a una dieta estándar del laboratorio, que contenía $23 \%$ de proteínas; 2) con restriccion de proteínas y energía (PER) - acceso libre a una dieta isoenergética, con restricción de proteínas, conteniendo un $8 \%$ de éstas y 3) grupo con restricción de energía, alimentado con restricción en la cantidad de alimento de la dieta estándar del laboratorio (ER). Al destete, todas las crías fueron separadas y recibieron las dietas establecidas hasta los 90 días (d90), luego fueron anestesiadas y sacrificadas. Las mediciones de las mandíbulas de las crías de rata fueron obtenidas por 3 puntos anatómicos preestablecidos. El análisis morfométrico de la mandíbula demostró que la mayoría de las mediciones en los grupos ER y PER eran significativamente menores que las del grupo control, con mayores reducciones en el grupo PER. Estos resultados muestran que las restricciones de energía y proteínas durante la lactancia tienen una influencia importante en el desarrollo de la mandíbula de las crías, las que se mantuvieron con el paso del tiempo.

PALABRAS CLAVE: Crecimiento y Desarrollo; Morfometría; Ratas; Mandibula; Desnutrición.

\section{REFERENCES}

Alippi, R. M.; Meta, M. D.; Olivera, M. I.; Bozzini, C.; Schneider, P.; Meta, I. F. \& Bozzini, C. E. Effect of protein-energy malnutrition in early life on the dimensions and bone quality of the adult rat mandible. Arch Oral Biol., 47(1):47-53, 2002.

Barker, D. J. In utero programming of cardiovascular disease. Theriogenology, 53(2):555-74, 2000.

Bayne, K. Revised Guide for the Care and Use of Laboratory Animals available. Physiologist., 39(4):199, 208-11, 1996.
Brogan, R. S.; Fife, S. K.; Conley, L. K.; Giustina, A. \& Wehrenberg, W. B. Effects of food deprivation on the $\mathrm{GH}$ axis: immunocytochemical and molecular analysis. Neuroendocrinology, 65(2):129-35, 1997.

Cameron, G. N. \& Eshelman, B. D. Growth and reproduction of hispid cotton rats (Sigmodon hispidus) in response to naturally occurring levels of dietary protein. J. Mammal., 77(1):220-31, 1996.

Chen, H.; Hayakawa, D.; Emura, S.; Ozawa, Y.; Okumura, 
DEGANI JUNIOR, H. V. M.; NUNES, V. A.; BEZERRA, E. C.; RAMOS, C. F.; RODRIGUES, M. R.; ABIDU-FIGUEREIDO, M.; CARDOZO, G. P. \& BABINSKI, M. A. Maternal food restriction during lactation reduces mandible growth of the female offspring in adulthood: Experimental and morphometric analysis. Int. J. Morphol., 29(2):598-603, 2011.

T. \& Shoumura, S. Effect of low or high dietary calcium on the morphology of the rat femur. Histol. Histopathol., 17(4):1129-35, 2002.

Cónsole, G. M.; Jurado, S. B.; Oyhenart, E.; Ferese, C.; Pucciarelli, H. \& Gómez Gomez, C. L. Morphometric and ultrastructural analysis of different pituitary cell populations in undernourished. Braz. Med. Biol. Res., 34(1):65-74, 2001.

Cotheran, E. G.; Aivaliotis, M. J. \& Vandeberg, J. L. The effects of diet on growth and reproduction in the shorttailed opossums (Monodelphis domestica). J. Exp. Zool., 236(1):103-14, 1985.

Delemarre-van de Wall, H. A.; van Coeverden, S. C. \& Engelbregt, M. T. Factors affecting onset of puberty. Horm. Res., 57(Suppl 2):15-8, 2002.

Desai, I. D.; Garcia Tavares, M. L.; Dutra de Oliveira, B. S.; Douglas, A.; Duarte, F. A.; Dutra de Oliveira, J. E. Food habits and nutritional status of agricultural migrant workers in Southern Brazil. Am. J. Clin. Nutr., 33(3):7024, 1980 .

Engelbregt, M. J.; Houdjik, M. E.; Popp-Snijders, C. \& Delemarre-van de Waal, H. A. The effects of intra-uterine growth retardation and postnatal undernutrition on onset of puberty in male and female rats. Pediatr. Res., 48(6):803-7, 2000.

Fernandes, R. M. P.; Abreu, A. V.; Schanaider, A; Soares Jr., E. R.; Peçanha, G. C. A.; Babinski, M. A. \& Ramos, C. F. Effects of Protein and Energy Restricted Diet During Lactation Leads to Persistent Morphological Changes on Tibia Growth in the Weaned Pups. Int. J. Morphol., 25(3):565-71, 2007.

Fernandes, R. M.; Abreu, A. V.; Silva, R. B.; Silva, D. F.; Martinez, G. L.; Babinski, M. A. \& Ramos, C. F. Maternal malnutrition during lactation reduces skull growth in weaned rat pups: Experimental and morphometric investigation. Anat. Sci. Int., 83(3):123-30, 2008.

Fischbeck, K. L. \& Rasmussen, K. M. Effect of repeated reproductive cycles on maternal nutritional status, lactational performance and litter growth in ad libitum fed and chronically food-restricted rats. J. Nutr., 117(11):1967-75, 1987.

Kasper, D. L.; Fauci, A. S.; Longo, D. L.; Braunwald, E.; Hauser, S. L. \& Jameson, J. L. Harrison's principles of internal medicine. $16^{\text {th }}$ ed. New York, McGraw-Hill, 2005.
Kawahara, T.; Shimokawa, I.; Tomita, M.; Hirano, T. \& Shindo, H. Effects of caloric restriction on development of the proximal growth plate and metaphysis of the caput femoris in spontaneously hypertensive rats: microscopic and computer-assisted image analyses. Microsc. Res. Tech., 59(4):306-12, 2002.

Kenney, M. A.; McCoy, H. \& Williams, L. Effects of magnesium deficiency on strength, mass, and composition of rat femur. Calcif. Tissue Int., 54(1):449, 1994.

Lucas, A. Programming by early nutrition: an experimental approach. J. Nutr., 128(2 Suppl):401S-6S, 1998.

Medeiros, D. M.; Plattner, A.; Jennings, D. \& Stoecker, B. Bone morphology, strength and density are compromised in iron-deficient rats and exacerbated by calcium restriction. J. Nutr., 132(10):3135-41, 2002.

Miller, S. C. \& Bowman, B. M. Comparison of bone loss during normal lactation with estrogen deficiency osteopenia and immobilization osteopenia in the rat. Anat. Rec., 251(2):265-274, 1998.

Miller, J. P. \& German, R. Z. Protein malnutrition affects the growth trajectories of the craniofacial skeleton in rats. J. Nutr., 129(11):2061-9, 1999.

Morohashi,T.; Ohta, A. \& Yamada, S. Dietary fructooligosaccharides prevent a reduction of cortical and trabecular bone following total gastrectomy in rats. Jpn. J. Pharmacol., 82(1):54-8, 2000.

Moura, A. S.; Carpinelli, A. R.; Barbosa, F. B.; Graverna, C. \& Mathias, P.C. Undernutrition during early lactation as an alternative model to study the onset of diabetes mellitus type II. Res. Commmun. Mol. Pathol. Pharmacol., 92(1):73-84, 1996.

National Research Council (NRC). Nutrient requirements of laboratory animal. Washington, National Academic Press, 1995.

Passos, M. C. F.; Ramos, C. F. \& Moura, E.G. Short and long term effects of malnutrition in rats during lactation on the body weight of offspring. Nutr. Res., 20(11):1603-12, 2000.

Pucciarelli, H. M. Growth of the functional components of the rat skull and its alterations by nutritional effects. Am. J. Phys. Anthropol., 56(1):33-41, 1981. 
DEGANI JUNIOR, H. V. M.; NUNES, V. A.; BEZERRA, E. C.; RAMOS, C. F.; RODRIGUES, M. R.; ABIDU-FIGUEREIDO, M.; CARDOZO, G. P. \& BABINSKI, M. A. Maternal food restriction during lactation reduces mandible growth of the female offspring in adulthood: Experimental and morphometric analysis. Int. J. Morphol., 29(2):598-603, 2011.

Pucciarelli, H. M. \& Oyhenart, E. E. Effects of maternal food restriction during lactation on craniofacial growth in weanling rats. Am. J. Phys. Antropol., 72(1):67-75, 1987.

Quinn, R. Editorial opinion: Comparing rat's to human's age: How old is my rat in people years? Nutrition, 21(6):775-7, 2005.

Ramos, C. F.; Lima, A. P.; Teixeira, C. V.; Brito, P. D. \& Moura, E. G. Thyroid function in post-weaning rats whose dams were fed a low-protein diet during suckling. Braz. J. Med. Biol. Res., 30(1):133-7, 1997.

Reeves, P. G.; Nielsen, F. H.; Fahey, G. C. Jr. AIN-93 Purified diets for laboratory rodents: final report of the American Institute of Nutrition Ad Hoc Writing Committee on the reformulation of the AIN-76 rodent diet. J. Nutr., 123(11):1939-51, 1993.

Riesenfeld, A. Biodynamics of head form and craniofacial relationships. Homo, 18:233-51, 1967.

Riesenfeld, A. The effect of extreme temperatures and starvation on the body proportions of the rat. Am. J. Phys. Anthropol., 39(3):427-59, 1973.

Rodriguez, P. N.; Friedman, S. M.; Boyer, P. \& de Portela, M. L. Influence of dietary calcium concentration on body size and bone composition in rats during recovery from malnutrition. J. Am. College. Nutr., 17(1):8691,1998 .

Santos, A. M.; Ferraz, M. R.; Teixeira, C.V.; Sampaio, F. J. $\&$ da Fonte Ramos, C. Effects of undernutrition on serum and testicular testosterone levels and sexual function in adult rats. Horm. Metab. Res., 36(1):27-33, 2004.

Teixeira, C.; Passos, M.; Ramos, C.; Dutra, S. \& Moura, E. Leptin serum concentration, food intake and body weight in rats whose mothers were exposed to malnutrition during lactation. J. Nutr. Biochem., 13(8):493, 2002.

Toews, J. G. \& Lee, M. Permanent skeletal growth retardation in the progeny of rats malnourished during pregnancy and lactation. Nutr. Nef. Int., 11:213-22, 1975.
Correspondence to:

Prof. Dr. Marcio Antonio Babinski

Department of Morphology

Biomedical Center

Fluminense Federal University

Av. Hernani Mello 101

CEP 24.210-150

Niterói, Rio de Janeiro

BRAZIL

Fax: (55) 21 2629-2336

Phone: (55) 21 2629-2332

Email: mababinski@gmail.com

Received: 01-01-2011

Accepted: 23-02-2011 